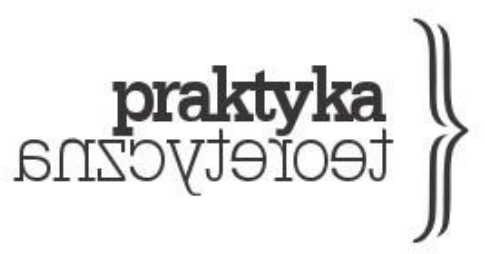

ISSN 2081-8130

DOI: $10.14746 /$ prt.2016.3.5 www.praktykateoretyczna.pl

\title{
UMKNĄĆ POCHWYCENIU. CO SCHIZOANALIZA OFERUJE TEORII MIGRACJI?
}

\author{
DAWID KUJAWA
}

\begin{abstract}
Abstrakt: W artykule zaprezentowane zostało schizoanalityczne spojrzenie na teorię migracji, a przede wszystkim na kwestię napięcia pomiędzy nieprzerwanie wzrastającymi przepływami mobilnej siły roboczej i władzą współczesnego, „płynnego” kapitału. Zestawiając tezy postawione przez najbardziej wpływowych teoretyków migracji (m.in. Sassen, Mezzadrę i Neilsona, Tsianosa, Papadopoulosa, Trimikliniotisa) z trzema pojęciami Gilles'a Deleuze'a oraz Féliksa Guattariego (kolejno: aparat pochwycenia, stawanie-się, nomadyczna maszyna wojenna), staram się wypracować nowe formuły subwersji w ramach dzisiejszych ruchów pracowniczych i migracyjnych. Pomimo że ta optyka nie proponuje żadnych jednoznacznych, zweryfikowanych taktyk oporu, jasno daje do zrozumienia, jakich form walki potrzebujemy współcześnie, by przeciwstawić się globalnej sieci nadzoru i wyzysku.
\end{abstract}

Słowa kluczowe: kontrola migracji, schizoanaliza, mobilne wspólnoty, obywatelstwo 


\section{Wstęp}

Przed dwudziestu laty badaczka globalizacji Saskia Sassen zwracała uwagę na fakt, że stopień kontroli migracji pozostaje właściwie bez znaczenia dla poziomu przestrzennych przepływów ludności: na zaostrzaniu polityki migracyjnej zawsze zyskuja podmioty odpowiedzialne za odpłatna pomoc w „nielegalnym”1 przekraczaniu granic, a wszelkie odgórne ustalenia prowadzące do zwiększania lub zmniejszania przepustowości legalnych kanałów transportu zmieniać mogą jedynie proporcję między liczbami ludzi korzystających z obydwu „infrastruktur” (Sassen 1996). Choć dziś na świecie ponad miliard osób to migranci, a zbiorowość ta, jak wiadomo, cały czas się powiększa (GMDAC 2015), problem rzekomego „kryzysu migracyjnego” ujmować należałoby inaczej, niż proponuja to przekazy wiodących mediów: bez wątpienia to wzmożone mechanizmy kontroli generuja sytuację „kryzysową” i dlatego stojące za nimi instytucje (chociażby powołana w 2016 roku The European Border and Coast Guard) w takich właśnie ramach próbują ująć mobilność jednostek, pozostająca nieodmiennie jedną z licznych sprzeczności kapitalizmu - zjawiskiem jednocześnie pożądanym i niebezpiecznym dla jego struktur. Niewykluczone, że w pewnym stopniu rację ma również Evelyn Encalada, gdy nadmienia, że zagadnienie migracji przyjęło w powszechnej opinii postać kryzysu wtedy, kiedy dotyczyć zaczęło w większości napływu „niebiałych” do tak zwanych rozwiniętych krajów liberalnej demokracji (Encalada 2013). Jedno jest pewne: problemy, o których mówi się dzisiaj w kontekście wzmożonej mobilności społeczeństwa, dotyczą raczej samego kapitalizmu i jego wewnętrznych napięć niż faktycznych kwestii związanych z przemieszczaniem się ludności.

W niniejszym artykule przyjrzeć chciałbym się nie tyle abstrakcyjnie pojmowanej migracji jako takiej, ale raczej procedurom - także tym procedurom, które nie są widoczne gołym okiem - stosowanym wobec migrantów oraz rozmaitym praktykom tych drugich (szczególnie praktykom tych, których status prawny pozostaje nieuregulowany). Swego rodzaju osią analizy uczynię trzy pojęcia zaproponowane przez Gilles'a Deleuze’a i Feliksa Guattariego (2015) w Tysiacu Plateau - będą to kolejno aparat pochwycenia, stawanie-się oraz nomadyczna maszyna wojenna; posłużą mi one jednak głównie do usystematyzowania rozpoznań teoretyków migracji, które w takich ramach nabiorą innego nieco charakteru. Istotna będzie dla mnie kwestia silnego związku między dwoma wspomnianymi wyżej fenomenami: kontrolą i oporem, relacja między nimi w optyce Deleuzjańsko-Guattariańskiej jawi się bowiem jako wysoce niejednoznaczna i zmienna. Używając tego konkretnego pojęciowego instrumentarium, wręcz

\footnotetext{
1 Podążając za częścią badaczy migracji, kwestie legalności i nielegalności przekraczania granic oraz pobytu na terytorium obcego państwa ujmował będę w cudzysłowie. Kategorie te mają arbitralny charakter i podporządkowane są interesom kapitału, choć więc na stałe weszły do słownika, nie powinny być machinalnie przyswajane.
} 
mimochodem wykazuje się to, jak działania służące początkowo ograniczaniu zdolności do samostanowienia migrantów, w pewnych okolicznościach moga zostać przejęte i wykorzystane w celach emancypacyjnych - rzecz jasna proces ten odbywa się również, nawet zdecydowanie częściej, kierując swój wektor w przeciwnym kierunku; interesować będą mnie obydwa przypadki.

Ta perspektywa nie ma służyć udowodnieniu, że terminy schizoanalityczne stanowia poręczne narzędzia do opisu zagadnienia mobilności we współczesnym kapitalizmie, co zostało to już zresztą wykazane w licznych pracach skoncentrowanych na migracjach lub nawiązujacych do tej kwestii w pewnym tylko stopniu (zob. Mezzadra i Neilson 2013; Papadopoulos, Stephenson, Tsianos 2008; Negri i Hardt 2005; Trimikliniotis, Parsanoglou i Tsianos 2015). Zależy mi przede wszystkim na tym, by wykorzystać tkwiący w DeleuzjańskoGuattariańskim systemie ontologicznym (dalece wykraczającym poza rozpoznania przedstawione w drugiej części Kapitalizmu $i$ schizofreniı) potencjał do konceptualizowania nowych praktyk oporu, których wirtualne zaistnienie w przestrzeni dyskursywnej nie byłoby możliwe w ramach odmiennego ujęcia problemu. Innymi słowy: trzy wymienione powyżej pojęcia mam zamiar zastosować - zachowując przy tym kontekst całego immanentystycznego projektu filozofów - w opisie dostrzeganych zjawisk i praktyk stosowanych przez migrantów, aby następnie za pomocą tych właśnie instrumentów rozpoznać, dalekie oczywiście od gotowych rozwiązań, nowe modele działania w starciach z układami globalnego kapitału.

\section{Włączanie. Polityka tożsamości i aparat pochwycenia}

Trzynaste plateau Deleuze i Guattari poświęcają pojęciu aparatu pochwycenia, które w pewnym stopniu przypominać może prezentowane wcześniej w Anty-Edypie, wyprowadzone z psychoanalizy Lacanowskiej „despotyczne znaczące” (Deleuze i Guattari 1983), w rzeczywistości jest jednak terminem zdecydowanie szerszym, włączającym niejako w swój zakres także ten powyższy. Jak większość schizoanalitycznych konceptów aparat pochwycenia łatwiej poddaje się definicji uwzględniającej jego jakości dynamiczne niż statyczne, znacznie łatwiej zatem opowiedzieć o tym, „co robi” aparat pochwycenia, niż „czym jest” w rzeczywistości. Z pewnością nie jest on metaforą z porządku symbolicznego, a funkcjonuje raczej w sposób metonimiczny, przybierać może różne postaci w zależności od tego, na jakiej warstwie aktualnie występuje, nie odsyłając przy tym „w górę” do jakiegoś idealnego modelu. Punktem wyjścia do opisu aparatu pochwycenia Deleuze i Guattari czynia państwo, nie oznacza to jednak wcale, że do niego się on sprowadza: „Wraz z państwem czy też aparatem pochwycenia wkracza ogólna semiologia, nadkodująca pierwotne semiotyki. Zamiast cech wyrażenia, które podążają za maszynowa gromada, państwo ustanawia formę wyrażenia, która zniewala gromadę [...]" (Deleuze i Guattari 2015: 550). Aparat pochwycenia stanowi innymi 
słowy czystą formę wewnętrzności, w przeciwieństwie do maszyny wojennej, która jest czystą formą zewnętrzności (Deleuze i Guattari 2015: 435).

Pochwycenie to ruch, który jawi się jako zawsze już wykonany, niemożliwy do dostrzeżenia wtedy, gdy ma miejsce (Deleuze i Guattari 2015: 527) i opierający się na swego rodzaju petryfikacji czy nadaniu sztywnych form przepływom pragnienia, wcześniej niepodporządkowanym konkretnym instancjom i nie służącym ich interesom ${ }^{2}$. Tak jak ziemia jest więc pochwyconym terytorium, które teraz przynosi właścicielowi rentę, tak praca jest pochwyconą zwykłą czynnością, przynosząca zysk kapitaliście, pieniądz zaś - pochwycona wymiana, przynoszacca procent bankierowi (Deleuze i Guattari 2015: 549). Odnotować należy, że pochwycenie ma charakter warstwowy, może zatem przebiegać jako proces ciagłego nadkodowywania - przykładowo, autarkiczne społeczeństwo pierwotne pochwycone zostaje przez aparat państwa, państwo zaś - nawet gdy jest państwem realizującym socjalistyczny model centralnego planowania - przez międzynarodowy rynek kapitalistyczny.

Tym, co interesować mnie będzie w kontekście powyższych rozważań szczególnie, są kwestie obywatelstwa, statusu prawnego migrantów, a także - ujmując rzecz jeszcze szerzej tożsamości migranckiej. Wyjątkowo użyteczna okazuje się tutaj zaproponowana przez Dimitrisa Papadopoulosa, Niamha Stephensona i Vassilisa Tsianosa (2008) koncepcja double-R axiom, w której główną rolę odgrywają dwie, przedstawione jako nieodłączne od siebie, kategorie: reprezentacja (representation) oraz prawa (rights). Schemat zarysowany przez badaczy nie jest szczególnie skomplikowany: zauważają oni, że aby walczyć o prawa, podmiot traktowany jako jednostka bądź grupa społeczna - legitymować się musi reprezentacją opartą na określonych fundamentach tożsamościowych; nie chodzi tu jednak o konieczność istnienia liderów przewodzących zbiorowości w duchu „społecznej awangardy” - reprezentację określonej społeczności stanowić może w tym rozumieniu nawet cała społeczność, jak miałoby to miejsce w ruchach o najwyższym poziomie zdemokratyzowania - lecz o przymus silnego osadzenia grupy w określonej konstrukcji podmiotowej, wyraźnego zakreślenia jej granic, a zatem ukonstytuowana jej wnętrza i zewnętrza - dopiero z pozycji jednostki włączonej w obręb społeczności możliwe jest zgłaszanie roszczenia do praw. Ujmując rzecz jeszcze prościej, wszelkie postulaty mają siłę wprowadzania zmian wtedy, gdy wiemy, w czyim imieniu

\footnotetext{
2 Pragnienie w ujęciu Deleuze’a i Guattariego jest zawsze pragnieniem-produkcją: nie wynika ono z braku, nie jest nim poprzedzone, ani przez niego wywołane, jak utrzymuje klasyczna psychoanaliza, ale stanowi proces twórczy. Nie ma ono więc związku z kastracją i kompleksem Edypa, a raczej ze Spinozjańskim conatus, dążeniem do samozachowania, Filozoficzny duet, pisząc o pragnieniu, wyraźnie rozróżnia jego dwa znaczenia: jako produkcji i jako nabywania: „W pewnym sensie tradycyjna logika pragnienia była w błędzie od samego początku. Platońska logika pragnienia zmusza nas do dokonania wyboru między produkecja i nabywaniem. Od chwili gdy sytuujemy pragnienie po stronie nabywania, czynimy pragnienie idealistycznym (dialektycznym, nihilistycznym) pojęciem, które każe nam patrzeć w stronę pierwotnego braku. Braku obiektu, braku realnego obiektu” (Deleuze i Guattari 1983: 25). Argumentując za istnieniem pragnienia-produkcji, autorzy otwierają jednocześnie furtkę do powiązania tej kwestii z zawiązywaniem aliansów, ze zbiorową mocą polityczną - rozwijam ten wątek na s. 9., odnosząc się do Spinozjańskiego potentia.
} 
zostaja wyrażone (Papadopoulos, Stephenson, Tsianos 2008). Rozważania te w dużej mierze inspirowane są rzecz jasna niemożliwością swobodnego kontynuowania w kolejnych odsłonach tak zwanej „polityki tożsamościowej” współcześnie, bo choć odcisnęła ona silne piętno na rzeczywistości lat 80. (gdy ruchy feministyczne, antywojenne i LGBTQ nabrały partykularystycznego charakteru), dziś zdecydowana większość tego typu taktyk łatwo dała się zreterytorializować, kolektywy uprawiające taki właśnie model oporu zaś bez trudu wypracowały kompromis z neoliberalnymi formami zarządzania - krótko mówiąc, polityka tożsamościowa została podporządkowana kapitalistycznemu aparatowi pochwycenia (Sassen 2007, Hardt i Negri 2005). Deleuzjańska reterytorializacja oznacza stabilizację, organizację i swoiste „zamknięcie” tego, co początkowo miało postać niepodporządkowanego pragnienia, to zaś, jak zakłada schizoanaliza, ma charakter rewolucyjny i emancypacyjny, dopóki nie zostanie zaprzęgnięte $\mathrm{w}$ tryby maszyn pracujących na rzecz społecznych represji - powyższy przykład jest modelowy dla tego procesu.

Spora część imigrantów w swoich działaniach aktywistycznych walczy dziś wyłącznie o legalizację pobytu w obcym kraju (Trimikliniotis, Parsanoglou i Tsianos 2015: 38): osoby starające się o prawne włączenie w obręb danego państwa bądź o status obywatela nie są zatem podmiotami kontestacji, lecz raczej jednostkami umacniającymi status quo obowiązującego prawa migracyjnego. W takiej sytuacji nie mamy do czynienia z przekształcaniem kategorii obywatelstwa w ramach prób kwestionowania praktyk inkluzji i ekskluzji, ale z jednoznacznym aktem opartym na aspirowaniu do bycia „subsumowanym” pod konkretną agendę, cechująca się bardzo silną reprezentacja, a zatem i posiadającą liczne prerogatywy. Przykład obywatelstwa, choć jest ono kategorią starszą i nie do końca pokrywającą się z polityką tożsamościową, w pewien sposób unaoczniać może jej paradoks: kategoria ta musi opierać się na jednoznacznym nakreśleniu linii między wnętrzem i zewnętrzem, musi pozostawać wykluczająca, aby ci, którzy poddani są inkluzji, mogli zachować swoje prawa, prawa bowiem działać moga wyłącznie kosztem jednostek praw pozbawionych. Obywatelstwo rozszerzone na wszystkie jednostki staje się zbędne, zostaje pozbawione potencji przypisanej mu jedynie w okolicznościach nierównego układu sił między uprzywilejowanymi i podporządkowanymi (Trimikliniotis, Parsanoglou i Tsianos 2015: 28).

Jednocześnie rzecz jasna trudno osoby starające się o legalizację pobytu oskarżać o oportunizm. Warunki życia w obcym miejscu, bez zabezpieczeń socjalnych, prawa do opieki medycznej i gwarancji utrzymania stanowiska pracy - w tych okolicznościach oczywiście na czarnym rynku - zmuszają do działań mających na celu choćby nieznaczną poprawę sytuacji bytowej. Warto zwrócić jednak uwage, jak opresyjną maszyną aparat pochwycenia staje się dla tych właśnie jednostek, nie walczących z restrykcyjnym prawem migracyjnym, ale honorujących je i ubiegających się o inkluzję w ramach tychże regulacji. Doskonałym przykładem jest tutaj Kanada, w której funkcjonuja niezwykle ostre normy legalizacji pobytu cudzoziemców, 
„niejawnie" reprezentujące wszystkie najczęstsze formy dyskryminacji, mające w tym wypadku na celu reprodukcję i ochronę „ciała narodu” (McDonald 2011). Pomijając już oczywiste kwestie związane z uprzywilejowywaniem osób heteroseksualnych za sprawą strategii „łączenia rodzin”, politykę całkowicie wykluczająca osoby z kryminalną przeszłością czy klasistowskie praktyki nadawania „pierwszeństwa” osobom o wyższym poziomie stabilności ekonomicznej, koniecznie zwrócić trzeba uwagę na problem zaawansowanych badań zdrowotnych, których wyniki decydują o wydaniu pozwolenia na pobyt w kraju lub odrzuceniu wniosku. Oprócz Kanady także USA, Australia oraz Nowa Zelandia stosuja taki podskórnie rasistowski model regulacji - a według Jeana McDonalda już samo to określenie przywodzi na myśl Foucaultowską normalizację (Foucault 2011) - w jego ramach przyjazd obcokrajowca uznaje się za potencjalne zagrożenie dla biopolitycznego porządku społecznej tkanki.

Uzyskanie statusu „legalnego” imigranta jest oczywiście kwestią znacznie bardziej skomplikowana, niż może to wynikać z powyższych rozważań - dzisiejsze prawa migracyjne w oczywisty sposób mogą służyć jako dowód na względną deterytorializację zachodzącą w ramach cywilizowanej maszyny kapitalistycznej (zob. Deleuze i Guattari 2015: 66-67, 162, 544-545). Jak wykazuja Sandro Mezzadra i Brett Neilson, granica nie ma dziś wyłącznie charakteru terytorialnego, lecz także - jak wynika z ich rozpoznań - znacznie bardziej istotny charakter czasowy, sama inkluzja z kolei nie jest już procesem następującym raz na zawsze, ponieważ angażuje wielu aktorów i ma charakter stopniowalny: właściwe uregulowanie prawnego statusu nie oznacza bowiem jeszcze wcale zrównania praw przyjezdnych i „gospodarzy”. Wynika to już z samego aksjomatu podwójnego R: posiadanie reprezentacji nie musi iść w parze $z$ otrzymaniem praw należnych danej grupie, nie jest ona warunkiem wystarczalnym, bowiem włączenie w jej obręb może mieć wyłącznie charakter fasadowy. (Pamiętać musimy na przykład o praktykach takich jak differential inclusion [Mezzadra i Neilson 2010], segmented asimillation [Portes i Rumbaut 2001] czy differential exclusion [Castles i Davidson 2000] $)^{3}$.

Dobrze obrazuje to przykład hinduskich pracowników branży IT emigrujących w poszukiwaniu pracy do Australii - kraju przyjmującego na dłuższy pobyt wyłącznie pracowników „wysoko wykwalifikowanych” (to zreszta bardzo kłopotliwa kategoria, szczególnie w czasach kryzysu prawa wartości opartej na pracy: wysokie kwalifikacje nie przekładają się przecież na wyższy stopień produkcji wartości, choć bezpośrednio wpływają na płace). Jak zwracają uwagę Mezzadra i Neilson, coraz częstsza praktyka jest umożliwianie przez pracodawców młodym, wykształconym, anglojęzycznym Hindusom przyjazdu do Sydney zgodnie z regulaminem wizy 457 -bardzo często chodzi jednak nie tyle o zwykłe zatrudnienie,

3 Terminy te odnoszą się kolejno do strategii częściowego, niepełnego (warunkowego czy czasowego) włączania migrantów w obręb grupy, do podatności poszczególnych grup na rozmaite formy asymilowania kolejnych pokoleń migrantów oraz do działań mających na celu uniknięcie stałego osadnictwa migrantów. 
a o produkowanie tzw. benching migrants: to, że przyjezdny może „legalnie” osiedlić się w kraju jako pracownik branży IT, nie oznacza wcale, że będzie w swojej branży pracował; siła robocza, którą dysponuje, staje się siłą roboczą do „wydzierżawienia” od rzekomego pracodawcy umożliwiającego przyjazd, na co dzień jednak ów highly skilled migrant, by się utrzymać, parać będzie musiał się na przykład prowadzeniem taksówki lub pracą w sklepie (Mezzadra i Neilson 2013, 131-136).

Płynność terytorialnych granic, których uszczelnienia i rozszczelnienia determinowane sa zazwyczaj dynamiką rynku, nie zaś względami bezpieczeństwa czy pobudkami etycznymi, świetnie oddaje też przykład tak zwanych holding camps: odwlekanie procedury przyznania statusu azylanta czy uchodźcy osobie przybyłej do kraju „nielegalnie” lub w ogóle nieposiadającej dokumentów nie jest tak silnie związane z troską o jego przyszłe zabezpieczenie materialne czy pomyślny przebieg procesu integracyjnego, jak można by się spodziewać. Podkreślić należy, że w niektórych krajach osoby poszukujące azylu mogą zostać zatrzymane na każdym etapie ubiegania się o status bez otrzymania informacji o powodach takiej decyzji, a maksymalny czas internowania nie jest określony prawnie; średni czas aresztowania w Wielkiej Brytanii to zwykle od 8 do 12 miesięcy, w Australii jednak odnotowano przypadki nawet pięcioletniego przetrzymywania imigrantów (Goldin, Cameron, Balarajan 2011).

Kluczem do zrozumienia sposobu działania ośrodków przetrzymujących migrantów oraz przepisów odwlekających ich aktywność na rynku pracy jako elementów aparatu pochwycenia jest pojęcie zasad cyrkulacji kapitału we współczesnym świecie. Mamy tu do czynienia z kolejna, niemożliwą do przezwyciężenia, a wcześniej znacznie trudniejszą do dostrzeżenia sprzecznościa kapitalizmu: granice państw sa dziś coraz szerzej otwierane na operacje finansowe oraz transport towarów, a jednocześnie coraz szczelniej zamykane na przepływ ciał - problem jednak w tym, że kapitał nie obejdzie się bez towaru, jakim jest siła robocza, w swej istocie nieoddzielna przecież od ludzkiego ciała. Jedynym sposobem na przejęcie kontroli nad ruchem tego ostatniego jest stworzenie odpowiedniego systemu regulacji - w tym obozów przetrzymywania „zapasowej” siły roboczej, na którą zapotrzebowanie jeszcze na rynku nie wystapiło (Mezzadra i Neilson 2013, 149), ale w końcu może się pojawić. Wraz z miejscami pracy dla jednostek „wysoko wykwalifikowanych” - prawników, programistów, spekulantów giełdowych - rośnie popyt na siłę roboczą w sektorze usług. Jak powtarza Saskia Sassen: częstokroć kładziemy dziś tak silny nacisk na kwestię pracy niematerialnej, że zapominamy, iż ma ona miejsce w realnie istniejącej przestrzeni (Sassen 2007).

Wskazane wyżej problemy wskazują dość wyraźnie, że w tym kontekście kwestia działania aparatu pochwycenia nie jest tak prosta, jak można by początkowo zakładać z pewnością pochwycenie nie jest jednoznacznym, opartym na prawnej regulacji statusu gestem legalizacji pobytu jednostki w kraju. Pochwycenie nie oznacza pełnego włączenia, wówczas nie miałoby bowiem ono aż tak opresyjnego charakteru, a poza tym w tego rodzaju 
okolicznościach istniałaby prosta droga ucieczki przed nim samym, zaś linie ujścia, jak wiadomo, każdorazowo wymagają odkrycia i nieraz usytuowane są najmniej oczekiwanych miejscach. Pochwycenie ujmować należałoby raczej jako wytworzenie specyficznie rozumianej kategorii migranta, który zawsze skazany jest na regulację swojego statusu: to zewnętrzne wobec niego i podporządkowujące go sobie instancje decydują o stopniu jego inkluzji, ekskluzji (ta bowiem wbrew pozorom również może być tonowana) lub czasie jego pozostawania „w zawieszeniu”. Bez wątpienia znakiem czasów jest silnie zdeterytorializowany charakter tegoż aparatu: wystarczy zwrócić uwagę na fakt, jak niejednoznaczny jest z prawnego punktu widzenia tranzyt ludności w Turcji, koyun ticareti czyli „handel owcami” - w procesie tym biora udział setki ściśle współpracujących ze sobą aktorów, od przemytników aż po straż graniczną i policję. Ustalenie stopnia „legalności” konkretnych procedur jest w tym przypadku właściwie niemożliwe (Papadopoulos, Stephenson i Tsianos 2008, 212).

Powyższy wywód, choć stanowi jedynie zarys problemu, skłania już do postawienia kilku kwestii, z którymi zmierzyć będę się próbował w kolejnych dwóch częściach tekstu, poświęconych kolejno bliskim sobie tematom stawania-się i nomadycznej maszyny wojennej. Podstawowe byłyby dla nas w tym kontekście dwa pytania i kilka drobniejszych zagadnień orbitujących wokół nich: czy możliwe jest ujście aparatowi pochwycenia, skoro jest on dziś silnie zdeterytorializowany i jego sposób działania dotyczy tak imigrantów prawnie „włączonych”, jak i tych uznanych za „nielegalnych”, a nawet tych, których status przez wiele lat pozostaje niejasny? Jeśli tak, to czy możliwe jest, wbrew aksjomatowi podwójnego $\mathrm{R}$, podjęcie walki o prawa migrantów poza polityką tożsamościowa, która wiernie stoi na straży aparatu pochwycenia (i której mechanizmy, chcąc nie chcąc, już tutaj mocno dają nam się we znaki, jako że na tym poziomie refleksji nie jesteśmy w stanie uniknąć kategorii „migranta”)? Te pytania z kolei bezpośrednio odsyłają nas już do zagadnienia stanowiącego tu być może najwyższą stawkę - autonomii migracji.

\section{Przestać być migrantem. Polityka stawania-się}

Spojrzenie na problem mobilności przez pryzmat autonomii migracji opiera się na podstawowym założeniu, że migracji samej w sobie nie traktujemy po prostu jako efektu politycznych i ekonomicznych ingerencji państw neokolonizujących obszary, z których następnie „releguje” się w świat obywateli, ale jako całościową formację, polityczną siłę aktywnie kształtująca rzeczywistość. Nie oznacza to oderwania zagadnienia migracji od kwestii determinujących ja w oczywisty sposób: interwencji zbrojnych w krajach arabskich, nieprzerwanej ekspansji kapitalizmu i związanej z nią eksploatacji „Południa-Wschodu”, ale raczej odwrócenie kierunku rozważań, zwykle dyskursywizujących ruch ludności tak, by był on przede wszystkim badany jako skutek działań innych, silnych i sprawujących realną władzę 
aktorów. Pozwala to przede wszystkim wyjść poza zniekształcająca cały problem dychotomię kapitalistycznej eksploatacji i komunitarystycznej wiktymizacji migrantów: wsparcie dla mobilnych jednostek zwykle fundowane jest dziś bowiem głównie albo na potrzebach rynku pracy, albo na zasadach powierzchownego, niezwykle opresyjnego w gruncie rzeczy humanitaryzmu, który raczej wyraża elitarność filantropów, niż stanowi sygnał pożądanej solidarności (zob. Papadopoulos, Stephenson i Tsianos 2008, 203)

Taka metoda rzecz jasna zadłużona jest w filozofii politycznej Benedykta Spinozy, zaprzęgając w swoje tryby pojęcia i narzędzia konceptualizowania problemów o zdecydowanie afirmatywnym charakterze. Uczynienie migracji i migrantów kategoriami aktywnymi w tym układzie sił i uznanie biernego charakteru instrumentów kontroli i regulacji możliwe jest dzięki odniesieniu się do Spinozjańskiego rozróżnienia na potentia i potestas: władza sprawowana nad wielością jest niczym innym jak wynikiem oddania pola aparatom „rządzenia ludźmi”, w gruncie rzeczy pozbawionym jakiejś wyższej, podporządkowującej je sobie mocy, a dysponującym jedynie przejęta, odpowiednio skierowaną i uregulowaną mocą samej wielości (Spinoza 2009). Tą linią podążała oczywiście również włoska myśl operaistyczna i postoperaistyczna - sprawcza siła robotników pozwoliła ująć kapitał jako reaktywny element procesu produkcji i rozwinąć koncepcję robotniczej autonomii.

Łatwo zauważyć można, że natrafiamy tu na dość istotną barierę: ujęcie, jakie proponuje perspektywa autonomii migracji, nie pozwala samo z siebie na przekroczenie impasu, jaki wprowadza aksjomat podwójnego R: przyznać wręcz należy, że taka optyka prowadzić może do wzmacniania wymogu wyznaczenia silnych granic reprezentacji grupy wysuwającej roszczenia (następuje to, gdy migranci wyodrębniają się z wielości), w ontologicznym sensie wzmacnia bowiem status jej samej, jako że czyni z niej aktywnego aktora - zamiast produktu działań władzy - w społecznym układzie sił. Wyłonienie się podmiotu walki konieczne jest do stawienia czoła mechanizmom globalnego kapitału, jednocześnie jednak to ów „widoczny” i łatwy do zlokalizowania podmiot jest zaopatrzony w siłę roboczą, niezbędną do utrzymania kapitalistycznych warunków produkcji. Autonomia migracji odpowiada więc tak za „wyzwolenie” migracji spod reżimu, któremu ta jest podporządkowana, jak i za reprodukcje jego mechanizmów - to ciekawy przykład reterytorializacji następującej jednocześnie $\mathrm{z}$ deterytorializacją, można by powiedzieć nawet „w celu” deterytorializacji.

Zatem choć prawdziwym priorytetem migranta jest przestać być migrantem - tak jak celem robotnika jest przestać być robotnikiem (zob. Tronti 2005) - i umknąć aparatowi pochwycenia, aby tego dokonać, musi on ukonstytuować swoja podmiotowość właśnie jako aktywną i realnie oddziałującą na rzeczywistość siłę polityczną. Podobne okoliczności wymagaja od nas pomyślenia takiej taktyki konstruowania tożsamości, która umożliwiłaby wyjście poza zarysowany wyżej martwy punkt: czy można oprzeć polityczną siłę, obdarzoną dużym potencjałem zmiany rzeczywistości, na podmiocie, który gotowy jest włączać w swoje 
ramy nowe jednostki i jednocześnie uniknąć kontroli? Jeżeli w ogóle stworzenie takiego układu wchodzi w grę, trudno wyobrazić je sobie poza obrazem myśli, jaki proponuje filozofia Deleuze'a i Guattariego.

W swoich Trzech ekologiach, wydanych we Francji w roku 1989, drugi z nich pisał:

\begin{abstract}
Zamiast mówić o „podmiocie” powinniśmy raczej mówić o „komponentach subiektywizacj””, z których każdy pracuje na niego bardziej lub mniej. To powinno doprowadzić nas koniecznie do ponownego zbadania relacji pomiędzy pojęciami jednostki i podmiotu oraz, przede wszystkim, stworzenia wyraźnej dystynkcji między tymi dwoma. Wektory subiektywizacji niekoniecznie przechodzą przez jednostkę, która w rzeczywistości jawi się jako coś przypominającego „terminal” (podkr. - DK) dla procesów angażujących zespoły ludzi, socjoekonomiczne grupy, maszyny przetwarzające dane etc. (Guattari 2000, 36).
\end{abstract}

Pojęcie, którego używa francuski psychoterapeuta, aby nieco dokładniej przedstawić swoje ujęcie transwersalnej podmiotowości, okaże się dla nas szczególnie istotne przede wszystkim z dwóch powodów: wskazując na jej zmienny status ontologiczny, pozostający w intensywnej relacji z szeregiem zachodzących w rzeczywistości procesów (ostatecznie wcale nie zewnętrznych wobec niej, ale zachodzących na tej samej płaszczyźnie immanencji), właśnie na jej permanentne stawanie-się, włącza podmiotowość jednocześnie w kontekst migracyjny, sugerując, jakoby poczucie silnie osadzonego ,ja” - nie tylko w przypadku jednostek, ale i grup - było jedynie efektem chwilowego wstrzymania czy nawet po prostu spowolnienia i wyregulowania niezależnych przepływów pragnienia, ostatecznie działających na korzyść procesu subiektywizacji.

Stawanie-się, patrząc z tej perspektywy, byłoby czymś w rodzaju swobodnego korzystania z niezobowiązującego charakteru tak ujmowanej podmiotowości, eksperymentalnym „wychylaniem się” z przestrzeni Terytorium-terminalu w stronę innego terminalu, testując przy tym możliwości, jakie ruch taki zapewnia. Dla stawania-się najistotniejsze bodaj jest to, że nigdy nie kończy się ono „staniem się”, ale zawsze z czasem zmienia kierunek i prowadzi do innego stawania-się. Proces ten nie oznacza dosłownie rozumianego przekształcenia się w coś innego niż to, czym jesteśmy, ale dobrowolne wyjście naprzeciw nowemu sposobowi konceptualizowania własnej tożsamości. Słusznie zauważa Ian Buchanan, że Tysiac plateau jest w gruncie rzeczy propozycja nowej fenomenologii (Buchanan 2016), jako że jedno z najistotniejszych rozpoznań zawartych w tomie wyrażają wnioski dotyczące warstw, będących „zagęszczeniami na Ciele ziemi, jednocześnie molekularnymi i molowymi” (Deleuze i Guattari 2015, 622). Tożsamość jest abstrakcyjnym pofałdowaniem materii istniejącej na Ciele bez Organów (tzn. na płaszczyźnie, na której substancja nie jest zorganizowana, pozostaje w ruchu, nie utrwala się w postaci stałych elementów o niezmiennych funkcjach), która równie dobrze 
może zostać pofałdowana w inny sposób. Odnajdowanie nowych sposobów fałdowania, eksperymentowanie ze stanami pomiędzy jednym modelem uwarstwienia a innym, jest właśnie stawaniem-się, aliansem między tymi dwoma formami istnienia (zob. Deleuze 2014).

Choć pod kątem tego Deleuzjańsko-Guattariańskiego pojęcia badano już wątek migracji, jestem przekonany, że jego potencjał nie został wykorzystany w pełni - nie zmienia to jednak faktu, że autorzy tekstu, o którym mowa, wyznaczyli bardzo ciekawy kierunek dla dalszych badań. Papadopoulos, Stephenson i Tsianos skupiają się przede wszystkim na wątkach stawania-się-zwierzęciem oraz stawania-się-niewidzialnym (2008). Zwracając uwagę na nieludzki wymiar wymykania się reżimom regulującym mobilność ludzi, piszą o częstej konieczności pozbywania się przez migrantów dotychczasowej tożsamości, przerywania związku między nazwiskiem i ciałem. Badacze podkreślają „zwierzęcą" nomenklaturę funkcjonującą wśród przemytników ludzi na całym świecie („kojoty” na granicy Meksyk-USA, „rekiny” wśród brytyjskich marynarzy, „kruki” na granicy grecko-albańskiej, „wężogłowi” w Chinach), przede wszystkim jednak interesuje ich sytuacja tak zwanych Herraguas, „palaczy”, czyli zebranych w Tangerze migrantów pochodzących głównie z krajów arabskich i zachodniej Afryki, którzy w celu uniknięcia deportacji deklarują zamiar spalenia swoich dokumentów zaraz po przekroczeniu strefy Schengen w Hiszpanii. Stawanie-się-zwierzęciem to taktyka działania molekularnego, umożliwiająca zupełnie dosłowne wyzbycie się tożsamości, niezbędnej do bycia pochwyconym przez kategorię migranta: mobilny podmiot stający się nie-ludzkim wymyka się instrumentom nadzoru, sytuując się wobec nich tak, jak inne żywe nie-ludzkie organizmy. Nie sam gest zniszczenia dokumentów jest bowiem tutaj najistotniejszy - tracenie tożsamości jest długotrwała, wymagającą konsekwencji praktyką związaną ze zmianami codziennych przyzwyczajeń i pozbywaniem się swoich cech dystynktywnych (Papadopoulos, Stephenson, Tsianos 2008, 210-217). W szereg podobnych działań można by jeszcze zaliczyć chociażby takie akty jak świadome „odgrywanie” nieznajomości języka angielskiego w celu nienawiązywania współpracy z podmiotami dokonującymi kontroli itd.

Stawanie-się-niedostrzegalnym jest działaniem jeszcze bardziej radykalnym, niedostrzegalność jest bowiem „immanentnym końcem stawania się, jego kosmiczną formuła” (Deleuze i Guattari 2015, 338); stawać-się-niedostrzegalnym to „być jak wszyscy”, pozostawać poza strefą nadzoru dzięki skupieniu instrumentów kontroli na działaniach jednostek, a nie mas (te oczywiście podlegaja pewnemu nadzorowi, nie jest on jednak możliwy w takim stopniu jak po procesie indywidualizacji). Badacze migracji słusznie zwracają uwagę na rasistowski sposób przedstawiania procesów migracyjnych przez media czy organy Unii Europejskiej, trudno jednak zrozumieć, dlaczego akademicy o proweniencji deleuzjańskiej, jak choćby Thomas Nail, nie próbuja jednego, najczęściej chyba powracającego z tych obrazów odpowiednio „ograć” i wykorzystać we własnej argumentacji, właśnie w kontekście procesów stawania-sięniedostrzegalnym czy stawania-się-molekularnym. Myślę o metaforze „fali imigrantów 
zalewających Europę", która przypominać miałaby w tym ujęciu najazd barbarzyńców na Cesarstwo Rzymskie (Wolters i Nail 2015). Trudno nie zauważyć, że choć intencje używających tego rodzaju zwrotów Marine Le Pen czy Nigela Farage’a maja jednoznacznie represjonujący charakter, w przedstawieniach tych tkwi ogromny potencjał możliwy do wykorzystania w ramach polityki wielości: pozwalaja one pomyśleć migrację jako ruch jednocześnie wywierający potężny wpływ na rzeczywistość, stanowiący istotną siłę polityczną oraz odpodmiotowiony, jakby wygładzony, tzn. pozbawiony ziarnistości konstytuujących go jednostek, postrzeganych teraz jako jedna „sfora” czy „banda” (Deleuze i Guattari 2015). Choć więc odpodmiotowienie to pierwotnie miało na celu dehumanizacje wizerunku migranta i wykazanie jego niezdolności do asymilacji w „państwach rozwiniętych” (migrant pojawiający się jako niemal naturalna katastrofa, wywołujący chaos, plądrujący liberalny świat), warto wykorzystać je jako figurę politycznej afirmacji heterogenicznej tożsamości. Ujmowanie mobilności ludzi jako nieuchwytnego przepływu pragnienia, pracującego teraz w nowej przestrzeni, pozwala pozostać nam w rejestrach autonomii migracji, odrzucając jednocześnie politykę tożsamościową (czy „politykę widzialności”, jak nazwaliby to Papadopoulos, Stephenson i Tsianos), nie wyprowadzając przy tym refleksji poza immanentystyczny model postrzegania relacji społecznych.

Ciekawego przykładu stawania-się-obiektem (zob. McLean i Evans 2014), a zatem jeszcze innej taktyki mogącej znaleźć bardzo konkretne zastosowania w subwersywnej mikropolityce migracyjnej, dostarcza opowiadanie, czy raczej quasi-esej artysty Patricka Berniera zatytułowany $A$ Tale for Creating A Legal Precedent, który stał się kanwą performansu powstałego później w wyniku współpracy Berniera oraz Olive Martin. Bohaterka tekstu, sygnatariuszka listu do sądu administracyjnego, który wydał decyzję o jej natychmiastowej deportacji, nie tyle składa odwołanie, co raczej szczegółowo opisuje to, co dokładnie będzie miało miejsce wraz z jej przymusowym opuszczeniem terytorium państwa. Jako materiał dzieła sztuki, którego autorem jest artysta określany jako P., jej pamięć wraz z twórczym aktem stała się kulturowym dziedzictwem narodowym Zjednoczonego Królestwa Wielkiej Brytanii, w tym właśnie momencie na mocy prawa usuwanym z kraju. P. bowiem, zainspirowany wiadomościa o śmierci dwudziestoośmioletniego Irakijczyka próbującego przedostać się przez Eurotunel, zaczął angażować w swoje performansy imigrantów posiadających nieuregulowany status muzyków, storytellerów i tancerzy, którzy stawali się wykonawcami, ale przede wszystkim jedynym tworzywem zapisu autorskich dzieł; tym samym inicjowany był proces stawania-sięobiektem, zachodzący, co najciekawsze, zgodnie z literą prawa i jednocześnie radykalnie komplikujący prawną sytuację samych imigrantów. Rzecz jasna cały ten wymyk, ufundowany na politycznym wykorzystaniu autonomii sztuki, nie jest jednoznaczny i nie załatwia sprawy raz na zawsze: choć pozwala oderwać się podmiotowi od kategorii migranta, raz jeszcze poprzez usytuowanie go w nie-ludzkiej pozycji, nie umożliwia mu pełnego wydostania się spod reżimu 
kontroli, tak państwa, jak i kapitału, a raczej opiera się na przesunięciu akcentów w obrębie stosowanych represji. Stawanie-się-obiektem zaproponowane jako taktyka negocjowania granic bez wątpienia zawiera jednak pewien subwersywny potencjał: dosadnie wskazuje chociażby na paradoks funkcjonowania innych praw dla mobilnego kapitału stałego, innych zaś dla zmiennego. W szerszym oglądzie nie możemy przeoczyć innych jego konsekwencji (chociażby zatarcia granicy między towarem a żywą praca), które jednak nie sa przedmiotem niniejszego artykułu.

\section{Czysta forma zewnętrzności. Fala migracji jako maszyna wojenna}

W dwunastym plateau twórcy schizoanalizy komentują pojęcie, które posłużyć może nam do wskazania kreowanych przez imigrantów praktyk subwersji, wpływających pośrednio i bezpośrednio na zmianę organizacji rzeczywistości. Ponieważ działania te nie sa wprowadzane w życie z pozycji ,insiderów”, ale osób z administracyjnego czy praktycznego punktu widzenia permanentnie pozostających wykluczonymi z przestrzeni społecznej-czasem z ich własnej woli, co również ma tu znaczenie - swój wywód opieram na kategorii nomadycznej maszyny wojennej, zawsze „zewnętrznej wobec państwa”. Ów zewnętrzny charakter jej działania jest niezwykle istotny dla poruszanego tu wątku: rozmaite ruchy moga być wchłaniane przez molowe maszyny - państwo może pozyskać armię i włączyć wojnę w porządek prawny (Deleuze i Guattari 2015, 432) - ale wówczas działaja już na ich rachunek, wzmacniają je i w żadnym stopniu nie dążą do ich deterytorializacji.

Konieczne wydaje się w tym miejscu odnotowanie, że myśl Deleuzjańsko-Guattariańska zakłada rozróżnienie na migranta i nomadę: koczownik w tym ujęciu jest oczywiście sytuowany po stronie maszyny wojennej, powierzchni gładkiej, deterytorializacji, a zatem rozpoznawany jest jako ktoś (zaimek ten zresztą jest w tym kontekście nieco kłopotliwy), kto okupuje cała przestrzeń pomiędzy poszczególnymi punktami podróży, niestałymi i spełniającymi drugorzędną rolę. „Koczownicze życie to intermezzo” (Deleuze i Guattari 2015, s. 467), podczas gdy życie migranta podporządkowane jest miejscom, między którymi się przemieszcza, i to one stanowią istotę jego drogi. Idąc za rozważaniami teoretyków migracji (Wolters i Nail 2015; Papadopoulos, Stephenson, Tsianos 2008), rozróżnienie to uznaję za nieaktualne - sedno ruchów migracyjnych i procesów migracji określane jest dziś przez praktyki nomadyczne i właściwie nigdy nie opiera się na prostej translokacji z punktu do punktu. Nie argumentuję oczywiście za tym, że sytuacja współczesnego migranta nie jest determinowana przez uwarunkowania miejsca, w którym ten przebywa - chodziłoby raczej o to, że dzisiejsze formy ludzkiej mobilności częstokroć przyjmuja postać przemieszczania się bez wyznaczania określonego celu podróży; decyzja o opuszczeniu miejsca swojego osiedlenia w większej części przypadków nie jest jednoznaczna z decyzją o zmianie miejsca osiedlenia, ale z rozpoczęciem 
ruchu, którego zakończenie w danej chwili w ogóle nie znajduje się w horyzoncie działań i planów migranta.

Naturalnie uwzględnić trzeba problemy, jakie - raz jeszcze - wywołuje wielowarstwowość konkretnych zjawisk na płaszczyźnie immanencji: „Każda moc jest siła deterytorializacji, wchodzącą w sojusz z innymi siłami bądź się im przeciwstawiającą [...]. Każdy proces może wystąić w innej mocy, jednak może również podporządkować inne procesy swej własnej mocy" (Deleuze i Guattari 2015, 540). Mobilna, swobodnie przemieszczająca się sfora, jak ujęliby to filozofowie, która zostaje pochwycona, stając się tym samym grupa „nielegalnych imigrantów”, nadal stanowi maszynę wojenną względem kategorii obywatelstwa, jeżeli jednak wyklaruje się z niej jednolity podmiot polityczny o wspólnych doświadczeniach i roszczeniach, niewiele będzie mógł on zdziałać w kwestii zmiany podstaw samej kategorii „,imigranta”, nie będzie bowiem usytuowany na zewnątrz niej, lecz w samym jej centrum. Złożoność tej sytuacji dobrze obrazuje casus francuskich sans-papiers, którzy przyczynili się do redefinicji pojęcia obywatelstwa jako „kolektywnej praktyki”, a nie instytucji, i pozwolili Francuzom „lepiej zrozumieć, czym jest demokracja” (Balibar 1996). Zarazem ich roszczenia nie dotyczyły przecież przekształcania publicznej przestrzeni ani dokonania semantycznego przesunięcia w zakresie konkretnej kategorii, lecz właśnie uregulowania ich statusu, dzięki któremu mogliby liczyć na włączenie w sferę uprzywilejowania, bez zmiany sytuacji tych, którzy pozostaliby wciąż poza wytyczonymi granicami tej sfery. Tym samym ruch sans-papiers wyłonił się pierwotnie w postaci maszyny wojennej, która jako urządzenie dokonywała umiarkowanej deterytorializacji w społecznej sferze, ale jednostki składające się na to urządzenie z osobna dążyły przecież do bycia „zasymilowanymi” i objętymi ochrona, a więc, ni mniej, ni więcej, do rozbrojenia owej maszyny.

Precedens ten ma oczywiście dość paradoksalny charakter, nie oznacza to jednak, że polityczna aktywność „nielegalnych” imigrantów zawsze przebiega w podobny sposób. Jeśli interesują nas praktyki zachodzące na powierzchni gładkiej, nie zaś mocno posegmentowanej i wyżłobionej (to podstawowa różnica między działaniem nomadycznej maszyny wojennej i aparatu państwa), zwrócić uwagę powinniśmy na ruchy skłoterskie, które organizują się w tak zwanych arrival cities (Saunders 2010), czyli miejscach stanowiących swoiste przestrzenie tranzytowe, zwykle zasiedlanych tymczasowo przez imigrantów próbujących dotrzeć w głąb Europy. Nie trzeba dziś już chyba nikogo przekonywać do tezy, że to właśnie miasto jest polem najbardziej widocznych napięć społecznych i zupełnie dosłownie rozumianej walki o przestrzeń oraz dystrybucje praw (zob. Harvey 2012, Sassen 2007).

Funkcjonujacy w Atenach School Squat 2, jeden z czterech skłotów otwartych przez grupę lokalnych aktywistów, zamieszkuje obecnie około trzystu pięćdziesięciu osób, w tym około setki dzieci; nie funkcjonuje on jednak jako zorganizowane przez wolontariuszy schronienie dla tych, którzy „nielegalnie” przekroczyli granice lub uciekli z otoczonych drutami 
kolczastymi obozów - samoorganizacja rezydentów pozwala im realnie wpływać na kształt okolicznego życia społecznego poprzez organizacje warsztatów artystycznych, zajęć dla dzieci czy lekcji języka arabskiego (Moving Europe 2016). Podkreślić należy, że tego rodzaju działania nie sa, jak często się uznaje, odcięte od mainstreamowej polityki miejskiej: fakt, że samoorganizujący się migranci pozostają poza sfera „,centralnych” praktyk społecznych, nie oznacza wcale, że ich aktywności istnieją w izolacji. Dlatego właśnie warte są uwagi w optyce deleuzjańsko-guattariańskiej: jako maszyny wojenne, choć sytuują się na zewnątrz oficjalnego życia miejskiego, w istocie niezwykle silnie na nie wpływają, odblokowując linie ujścia w regułach rządzących miejskim życiem (zupełnie inną sprawą jest już natomiast to, co z regułami tymi dzieje się, gdy następuja reterytorializujące procesy gentryfikacyjne). Uprawianie takiego rodzaju polityki niedostrzegalności, taktycznego poruszania się po nieskodyfikowanych rejonach i schodzenia poniżej poziomu reprezentacji zmienia przestrzeń społeczną, choć jej zmiana nie jest tu główną intencją (Papadopoulos, Stephenson, Tsianos 2008); angażowanie lokalnych mieszkańców w taki rodzaj praktyk społecznych pozwala na przekraczanie dychotomii między dobrem publicznym i prywatnym, zupełnie przygodnie zaszczepia zatem w danej przestrzeni idee commoningu (zob. Linebaugh 2008). Skupiając się na doraźnych celach, maszyny wojenne przeprowadzają eksperymenty społeczne, które wyznaczaja nowe infrastruktury dla działań politycznych - jeszcze niepochwycone, niepodporządkowane - same maszyny jednak nie trzymają się owych infrastruktur, lecz wynajdują kolejne linie ujścia.

Maszyny wojenne mogą przybierać charakter rozmaitych układów, powstałych przy zintegrowanej pracy różnych elementów. Widać to chociażby w przypadku panującej w Nikozji niepisanej zasady bardzo specyficznych solidarnościowych aktów, jakie „legalni” imigranci okazuja tym o nieuregulowanym statusie. Ponieważ policja imigracyjna w tym mieście szczególnie często dokonuje aresztowań na przystankach autobusowych, cudzoziemcy posiadający dokumenty uprawniające ich do pobytu w kraju, zauważając patrol, uciekaja przed nim jako pierwsi, tym samym nie narażając się na duże niebezpieczeństwo, a jednocześnie ratując przed kontrolą osoby przebywające na tym terytorium „nielegalnie” (Trimikliniotis, Parsanoglou i Tsianos 2015). Zwróćmy uwagę, jak niejasny jest status tego układu, w ramach którego alians zawierają ze sobą jednostki z prawnego punktu widzenia włączone i wyłączone z obrębu społeczeństwa: pewna optyka nakazywałaby nam myśleć o tym akcie jako o mocno uwikłanym w politykę tożsamościową, w końcu mamy tu do czynienia z dwoma aktorami kategoryzowanymi jaki imigranci. Nie możemy jednak zlekceważyć kluczowego procesu, jaki tu zachodzi: jeden z elementów układu w zupełnie dosłowny sposób staje-się-nielegalnym, opuszcza bezpieczna pozycję imigranta o uregulowanym statusie (przestaje funkcjonować jako delegat „wewnętrznego” aparatu państwa) i działa w imieniu tej niepochwyconej, mglistej kategorii „nielegalnego” rezydenta - co najbardziej intrygujące, już w chwili zatrzymania 
i wylegitymowania go „nielegalność” po raz kolejny rozpływa się w powietrzu, w pełni ukazuje się jako funkcjonująca między tożsamością i jej brakiem. Nic z tych rzeczy nie byłoby jednak możliwe, gdyby jednostka działała poza wskazanym układem: rezultatem działania maszyny jest uderzenie w despotycznie narzuconą ramę „nielegalnego”, ale jej właściwym celem jest przecież stworzenie swoistej zasłony dla osoby zagrożonej przez narzędzie kontroli.

Nomadyczne maszyny wojenne nie pracują rzecz jasna wyłącznie w przestrzeniach miejskich; w ostatnich latach byliśmy świadkami wielu politycznych aktów o wyraźnie molekularnym - jednorazowym i spontanicznym - charakterze, które miały miejsce w obozach dla uchodźców czy na granicach państw. Liczne przypadki podpaleń „ośrodków przetrzymywania” w Tunezji, Grecji czy w Niemczech stanowią niezwykle klarowną ilustrację: tego rodzaju centra, jak było to już wspomniane, służą przede wszystkim kontroli przepustowości granic, nie tyle sprowadzając jednostkowe istnienia do „nagiego życia” (Agamben 2008), co - w pewnym sensie odwrotnie - bezosobowej „fali” nadając tożsamość, zakładając jej rodzaj biopolitycznej smyczy, która dopiero umożliwia zarządzanie indywiduami. Podpalenie obozu i ucieczka z niego, choć stanowia gesty doraźnego sprzeciwu wobec warunków panujących wewnątrz ośrodków, jednocześnie uderzają bezpośrednio w istotę aparatu pochwycenia, są odmowa przyjęcia imigranckiej podmiotowości i pozwalaja sforze zachować właściwy jej status wielości: „ [...] co za głupota, nie można być wilkiem, jest się zawsze ośmioma lub dziesięcioma wilkami, sześcioma lub siedmioma wilkami [...]” (Deleuze i Guattari 2015, 34). Wewnętrzny stosunek maszyny wojennej względem państwa jest tu oczywiście tylko pozorny, na co wskazuje opisany już wyżej efemeryczny status granic we współczesnym kapitalizmie: przetrzymywani imigranci nie są przecież włączeni, a jedyne poddawani pochwyceniu, któremu wymykają się podczas ucieczki z obozu.

Mnożyć można przykłady kolejnych, wyłaniających się z heterogenicznych mobilnych wspólnot maszyn wojennych, które za sprawa swojej nomadycznej polityki uchodzą mechanizmom pochwycenia i zmieniają kształt społecznych relacji, sytuując się jednocześnie zawsze poza rozpoznanymi formami oporu. Cała ich skuteczność opiera się jednak na tym, że nie można w całkowicie jednoznaczny sposób wytyczyć szlaków dla takich strategii: niepowtarzalne incydenty stanowią egzemplifikację tego, jak poszukiwać powinniśmy linii ujścia - mimo wszystko to już dość dużo.

\section{Próba wniosków}

Spojrzenie na teorię migracji z perspektywy nomadologicznej okazuje się ostatecznie cenne z kilku powodów: nie przynosi oczywiście gotowych rozwiązań dotyczących technik stawiania oporu mechanizmom kontroli granic i wyzysku (funkcjonujących, jak już zauważyliśmy, w pełnej symbiozie, a czasem nawet trudnych do odróżnienia), lecz prezentuje mimo to spójny 
model poszukiwania tego rodzaju technik i umożliwia skuteczniejsze lokalizowanie instrumentów represji. Kategoria aparatu pochwycenia w niezwykle przejrzysty sposób wskazuje, że nie mamy dziś do czynienia z prostym konfliktem na linii mobilna ludność globalny kapitał, lecz z ciąłym przenikaniem hierarchicznych struktur globalnego kapitału do samego wnętrza ruchów, które na celu mają odpieranie jego sił. Pochwycenie zawsze służy kontroli, dlatego nie może być dziś skuteczne jako element subwersywnych taktyk, co wykazał już impas polityki tożsamościowej. Współcześnie stajemy przed wyzwaniem wynajdowania nowych eksperymentów społecznych opartych na procesach stawania-się - płynnemu kapitałowi, który stara się petryfikować i „namierzać” siłę roboczą, odpowiedzieć może autonomiczna siła robocza, która stopniowo się upłynnia; elastyczność pracy postulowana przez neoliberalny porządek jest wybiórcza: linii ujścia poszukiwać powinniśmy tam, gdzie kapitał oczekuje trwałej, łatwej do zlokalizowania i kontrolowania pracy. Stąd konieczność zawiązywania mobilnych wspólnot na wzór „czystej formy zewnętrzności”, maszyny wojennej, nie zaś aparatu państwa - hierarchicznego w strukturze, bo łatwo poddającego się kolejnym nadkodowaniom.

Zdaniem Deleuze'a i Guattariego prędkość ściśle związana jest z bronią, ta z kolei przynależy maszynie wojennej, dla której typowe jest swobodne działanie, czyli niepochwycona przez kategorię pracy czynność; ciężar, z drugiej strony, odpowiada narzędziu - instrumentowi przynależnemu aparatowi państwa i służącemu do wykonywania pracy pochwyconej, czyli przynoszącej zysk kapitaliście (Deleuze i Guattari 2015, 487-498). Już to wysoce abstrakcyjne rozpoznanie jasno daje do zrozumienia, że potencjał tkwiący w mobilnych społecznościach ma siłę przeciwstawienia się kapitałowi, jeśli tylko pozostaną one mobilne na własnych warunkach. Opierając się na podobnych rozpoznaniach, można by wysnuć wniosek, że to właśnie ruchy migracyjne, składające się przecież z siły roboczej, wyznaczać powinny dziś nowe metody działania dla ruchów pracowniczych; jedno wiemy na pewno: sojusz pracowników i migrantów jest absolutnie niezbędny do zawiązania nowego internacjonalizmu w walce z globalną siecią wyzysku - a niewykluczone, że w przyszłości broń przyczyni się do odrzucenia narzędzi. 


\section{Wykaz literatury}

Agamben, Giorgio. 2008. Homo sacer. Suwerenna władza i nagie sycie. Tłum. Mateusz Salwa. Warszawa: Prószyński i S-ka.

Balibar, Étienne. 1996. "What we owe to the Sans-papiers". Tłum. Jason Francis McGimsey, Erika Doucette. http://eipcp.net/transversal/0313/balibar/en

Buchanan, Ian. 2016. [b.d]. https://www.youtube.com/watch?v=FIIpS3PPObY

Castles, Stephen i Davidson, Alastair. 2000. Citizenship and Migration. Citizenship and the Politics of Belonging. Basingstoke-London: Macmillan Press LTD.

Deleuze, Gilles i Guattari, Félix. 1983. Capitalism and Schizophrenia. Anti-Oedipus. Tłum. Robert Hurley, Mark Seem, Helen R. Lane. Minneapolis: University of Minnesota Press.

Deleuze, Gilles i Guattari, Félix. 2015. Kapitalizm i schizofrenia II. Tysiac plateau. Red. merytoryczna Joanna Bednarek. Warszawa: Fundacja Bęc Zmiana.

Deleuze, Gilles. 2014. Fałda. Leibniz a barok. Tłum. Mateusz Janik, Sławomir Królak. Warszawa: Wydawnictwo Naukowe PWN.

Encalada, Evelyn. 2013. [b.d]. https://www.youtube.com/watch?v=J3A9d6Bk 0o

Foucault, Michel. 2011. Narodziny biopolityki. Tłum. Michał Herer. Warszawa: Wydawnictwo Naukowe PWN.

Global Migration Data Analysis Centre [GMDAC]. “2015. Global Migration Trends Factsheet".

https://docs.google.com/viewerng/viewer?url=http://publications.iom.int/system/fil es/global migration trends 2015 factsheet.pdf\&hl=en US

Goldin, Ian; Cameron, Geoffrey i Balarajan, Meera. 2011. Exceptional People. How Migration Shaped Our World and Will Define Our Future. Princeton-Oxford: Princeton University Press.

Guattari, Félix. 2000. The Three Ecologies. Tłum. Ian Pindar, Paul Sutton. London - New Brunswick: The Athlone Press.

Hardt, Michael i Negri, Antonio. 2005. Imperium. Tłum. Sergiusz Ślusarski, Adam Kołbaniuk. Warszawa: Wydawnictwo W.A.B.

Harvey, David. 2012. Bunt miast. Prawo do miasta i miejska rewolucja. Tłum. „Praktyka Teoretyczna". Warszawa: Fundacja Bęc Zmiana.

Linebaugh, Peter. 2008. Magna Carta Manifesto. Liberties and Commons for All. Berkeley-Los Angeles-London: University of California Press.

McDonald, Jean. 2009. „Migrant Illegality, Nation-Building, and the Politics of Regularization in Canada." Refuge. Canada's Journal of Refugees 2: 65-77.

McLean, Chris i Evans, Gillian. 2014. „Becoming object. Introduction.” W Objects and Materials. Red. Penny Harvey, Eleanor Conlin Casella, Gillian Evans, Hannah Knox, Christine McLean, Elizabeth B. Silva, Nicholas Thoburn, Kath Woodward. LondonNew York: Routledge.

Mezzadra, Sandro i Neilson, Brett. 2013. Border as Method, or, the Multiplication of Labour. Duram-London: Duke University Press. 
Mezzarda, Sandro i Neilson, Brett. 2010. „Borderscapes of Differential Inclusion. Subjectivity and Struggles on the Threshold of Justice's Excess." W The Borders of Justice, red. Étienne Balibar, Sandro Mezzadra, Ranabir Samaddar. Philadephia: Temple University Press.

Moving Europe. 2016. „Refugee-Squats in Athens.” http://moving-europe.org/24-06-2016refugee-squats-in-athens

Papadopoulos, Dimitris; Stephenson, Niamh i Tsianos, Vassilis. 2008. Escape Routes Control and Subversion in the Twenty-first Century. London-Ann Arbor: Pluto Press.

Portes, Alejandro i Rumbaut, Rubén G. 2001. Legacies. The Story of the Immigrant Second Generation. Berkeley-Los Angeles-London: University of California Press; New York: Russel Sage Foundation.

Sassen, Saskia. 1996. Losing control? Sovereignty in An Age of Globalization. New York: Columbia University Press.

Sassen, Saskia. 2007. Globalizacja. Eseje o nowej mobilności ludæi i pieniędży. Przedm. K. Anthony Appiah. Tłum. Joanna Tegnerowicz. Kraków: Wydawnictwo Uniwersytetu Jagiellońskiego.

Saunders, Doug. 2010. Arrival City. How the Largest Migration in History is Reshaping Our World. New York: Pantheon Books.

Spinoza, Baruch. 2009. Traktaty. Etyka. Tłum. Ignacy Halpern. Warszawa: Hachette.

Trimikliniotis, Nicos; Parsanoglou, Dimitris i Tsianos, Vassilis S. 2015. Mobile Commons, Migrant Digitalities and the Right to the City. London: Palgrave Macmillan.

Tronti, Mario. 2005. „The Strategy of Refusal.” Przeł. [b.d]. https://libcom.org/library/strategy-refusal-mario-tronti

Wolters, Eugene i Nail, Thomas. 2015. „The Figure of the Migrant. An Interview with Thomas Nail". http://www.critical-theory.com/the-figure-of-the-migrant-an-interviewwith-thomas-nail/ 
Dawid Kujawa - Krytyk literacki, doktorant w Instytucie Nauk o Literaturze Polskiej im. Ireneusza Opackiego UŚ. Autor monografii Wideopoezja. Szkice (Katowice 2014). Obecnie pracuje nad rozprawa poświęcona powracającym tendencjom awangardowym w polskiej poezji po roku 2000 w kontekście jej polityzacji.

\section{DANE ADRESOWE:}

Instytut Nauk o Literaturze Polskiej im. Ireneusza Opackiego

Uniwersytet Śląski

plac Sejmu Śląskiego 1, p. 409.

40-032 Katowice

EMAIL: dawid.kujawa0@gmail.com

CYTOWANIE: Kujawa, Dawid. 2016. Umknąć pochwyceniu. Co schizoanaliza oferuje teorii migracji? Praktyka Teoretyczna 3(21): 118-137.

DOI: $10.14746 /$ prt.2016.3.5

AUTHOR: Dawid Kujawa

TITLE: To Escape the Capture. What Does Schizoanalysis Offer to Migration Theory?

ABSTRACT: The article applies the schizoanalytic approach to migration theory and focuses on the tension between the constantly growing flow of a mobile workforce and the power of the contemporary "liquid" capital. By juxtaposing the theses posed by critical migration scholars (Sassen, Mezzadra, Neilson, Tsianos, Papadopoulos, Trimikliniotis) with three concepts from Gilles Deleuze and Félix Guattari (the apparatus of capture; becoming; the nomadic war machine), the article elaborates on new modes of subversion. It claims they could be useful to labour and migration movements nowadays. Although such an approach does not provide any specific and verified means of resistance, it reveals what patterns of struggle are nowadays needed to oppose the global network of surveillance and exploitation.aimed to make free mobility possible are becoming its main source of danger.

KEYWORDS: migration control, schizoanalysis, mobile commons, citizenship 